\title{
Evaluating the Effect of Gamma Radiation on the Total Phenolic Content, Flavonoids, and Antioxidant Activity of Dried Pleurotus ostreatus ((Jacq. ex. Fr) Kummer) Stored in Packaging Materials
}

\author{
Nii Korley Kortei, ${ }^{1}$ George Tawia Odamtten, ${ }^{1,2}$ Mary Obodai, ${ }^{3}$ \\ Victoria Appiah, ${ }^{1}$ Felicia Akuamoa, ${ }^{4}$ Afua Kobi Adu-Bobi, ${ }^{4}$ Sylvester Nana Yao Annan, ${ }^{5}$ \\ Jonathan Nii Okai Armah, ${ }^{5}$ and Stanley Akwesi Acquah ${ }^{5}$ \\ ${ }^{1}$ Graduate School of Nuclear and Allied Sciences, Department of Nuclear Agriculture and Radiation Processing, \\ P.O. Box LG 80, Legon, Ghana \\ ${ }^{2}$ Department of Botany, University of Ghana, P.O. Box LG 55, Legon, Ghana \\ ${ }^{3}$ CSIR-Food Research Institute, P.O. Box M20, Accra, Ghana \\ ${ }^{4}$ Applied Radiation Biology Centre, Ghana Atomic Energy Commission, P.O. Box AE 1, Atomic, Accra, Ghana \\ ${ }^{5}$ Radiation Technology Centre, Ghana Atomic Energy Commission, P.O. Box AE 1, Atomic, Accra, Ghana \\ Correspondence should be addressed to Nii Korley Kortei; nii_korley_1@yahoo.com
}

Received 30 April 2014; Revised 22 July 2014; Accepted 31 July 2014; Published 24 August 2014

Academic Editor: Maria Cristina Bonferoni

Copyright (c) 2014 Nii Korley Kortei et al. This is an open access article distributed under the Creative Commons Attribution License, which permits unrestricted use, distribution, and reproduction in any medium, provided the original work is properly cited.

Dried Pleurotus ostreatus mushrooms stored in polythene and polypropylene packs were exposed to gamma radiation from a cobalt60 source at doses of $0,0.5,1,1.5$, and $2 \mathrm{kGy}$ at a dose rate of $1.7 \mathrm{kGy} / \mathrm{hr}$ and stored for a period of 1 month. Total phenolic contents, flavonoids, and free radical scavenging activity DPPH (2,2'-diphenyl-1-picrylhydrazyl) were determined using aqueous, ethanol, and methanol extracts by Folin-Ciocaultaeu method as a source of potential natural antioxidants. Total phenol content ranged $0.56 \pm$ 0.01-10.96 $\pm 1.7 \mathrm{mg} / \mathrm{GAE}$, flavonoids ranged $1.64 \pm 0.05-8.92 \pm 0.6 \mathrm{mg} / \mathrm{QE}, \mathrm{DPPH}$ radical scavenging activity also ranged $7.02 \pm 0.10-$ $13.03 \pm 0.04 \%$, and $\mathrm{IC}_{50}$ values also ranged $0.08-0.16 \mathrm{mg} / \mathrm{mL}$. Statistical differences $(P<0.05)$ were recorded for the extracts and the treatment doses of mushrooms stored in polythene and polypropylene packs. A significant linear correlation was confirmed between values for the total phenolic content and antioxidant activity of mushroom extracts. The high contents of phenolic compounds indicated that these compounds contribute to high antioxidant activity. Pleurotus ostreatus can be regarded as a promising candidate for natural mushroom sources of antioxidants with high value. The use of low dose gamma radiation by the local food industry could improve the hygienic quality, extend shelf-life, and preserve nutrients and antinutrients.

\section{Introduction}

Phenolic compounds are secondary metabolites that are derivatives of the pentose phosphate, shikimate, and phenylpropanoid pathways in living organisms [1-3]. They act in defense against pathogens, animal mycophage, or fungivore aggression and as response to various abiotic stress conditions, such as rainfall and ultraviolet radiation [4]. Polyphenols have protective activity which has been previously attributed to free radical scavenging, metal chelating properties, capability of inhibiting or reducing different enzymes, such as telomerase [5], cyclooxygenase $[6,7]$, or lipoxygenase [8,9], and then most importantly as antioxidant compounds with the ability to trap free radicals and thus 
inhibit the oxidative mechanisms. However, in more recent years, they play roles such as interacting with signal transduction pathways and cell receptors [10-12].

Naturally occurring antioxidants can be found in whole grains, fruits, vegetables, teas, spices, and herbs. Mushrooms have also been reported as living organisms with antioxidant activity which is correlated with their phenolic and polysaccharide compounds [13-15]. Their global economic value is now incredible, and the reason for the rise in consumption is a combination of their value as food $[16,17]$ and their medicinal or nutraceutical properties [18-21].

Harmful effects of disturbed antioxidant-prooxidant balance can be largely prevented by intake of antioxidant substances $[22,23]$. Antioxidants have already been found in mushroom materials and supplements $[24,25]$. Due to their natural origin, the antioxidants obtained from living organisms are of greater benefit in comparison to synthetic ones $[26,27]$. The use of natural antioxidants from mushrooms does not induce side effects, while synthetic antioxidants were found to have genotoxic effect $[28,29]$.

Free radicals, reactive nitrogen species (RNS), and other reactive oxygen species (ROS) such as superoxide anions, hydroxyl radicals, and hydrogen peroxide are an entire class of highly reactive species derived from the normal metabolism of oxygen or from exogenous factors and agents such as pollutants and ultraviolet (UV) radiation. According to $[30,31]$, oxidative damage to crucial cellular molecules, induced by ROS, has been implicated as a possible factor in the etiology of several human diseases such as cancer, cardiovascular diseases, atherosclerosis, Alzheimer disease, and ageing [32] reported that irradiated flavonoid solutions produce chemical reactions between the solute and reactive species, which are the result of the radiolyzed solvent. These reactions according to [32] take place in radiolyzed alcohol solutions, a medium that is very rich in many different highly reactive species and that hosts specific reactions. The reactivity of the solute (flavonoid) with the alkoxy radicals $\mathrm{CH}_{3} \mathrm{O}^{*}$ and $\mathrm{CH}_{3} \mathrm{CH}_{2} \mathrm{O}^{*}$ formed in methanol and ethanol, respectively, and their carbon-centered isomers: the 1-hydroxy-methyl ${ }^{*} \mathrm{CH}_{2} \mathrm{OH}$ and the 1-hydroxy-ethyl $\mathrm{CH}_{3}{ }^{*} \mathrm{CHOH}$ radicals operate to quickly repair the chemical modifications to biomolecules.

Published studies by several researchers [33, 34] show how polyphenol compounds in our diets help to improve endothelial function, which is a critical factor in preventing atherosclerosis. They have also been shown to inhibit the abnormal blood platelet aggregation that cause most sudden heart attacks and strokes, while fighting inflammation and supporting healthy blood lipids. They have the potential to reduce allergic conditions [35] by blocking the release of histamine (an irritating substance causing inflammation and itching) from the mast cells that mediate allergic reactions. Letenneur [36] reported that polyphenols from different natural sources may work synergistically when consumed together, with benefits from the combination resulting in more than the sum of the parts.

Antimicrobial activity of polyphenols occurring in vegetable foods, medicinal plants, and mushrooms has been extensively investigated against a wide range of microorganisms. Among polyphenols, flavan-3-ols, flavonols, and tannins received most attention due to their wide spectrum and higher antimicrobial activity in comparison with other polyphenols and to the fact that most of them are able to suppress a number of microbial virulence factors (such as inhibition of biofilm formation, reduction of host ligands adhesion, and neutralization of bacterial toxins) and show synergism with antibiotics [4]. The antimicrobial properties of certain classes of polyphenols have been proposed either to develop new food preservatives [37], due to the increasing consumer pressure on the food industry to avoid synthetic preservatives, or to develop innovative therapies for the treatment of various microbial infections $[38,39]$, considering the increase in microbial resistance against conventional antibiotic therapy.

This study is to investigate the effect of gamma radiation on total phenolic content, flavonoids, and antioxidant activity in various extracts of the species Pleurotus ostreatus in different packaging materials using spectrophotometric methods.

\section{Materials and Methods}

2.1. Chemicals. Analytical ethanol, methanol, and sodium hydrogen carbonate $\mathrm{NAHCO}_{3}$ were purchased from SigmaAldrich, USA. Standards of phenolic acids (gallic acid [3,4,5-trihydroxybenzoic acid]) and of flavonoids, potassium acetate, quercetin $\left[3,3^{\prime}, 4^{\prime}, 5,7\right.$-pentahydroxyflavone $]$, and 2,2-dyphenyl-1-picrylhydrazyl (DPPH) were obtained from Sigma Chemicals Co., St Louis, MO, USA. The FolinCiocalteu's phenol reagent and Aluminium chloride $\left(\mathrm{AlCl}_{3}\right)$ were from Fluka Chemie AG, Buchs, Switzerland.

2.2. Mushroom Material. Pleurotus ostreatus originally from Mauritius was cultivated on Triplochiton scleroxylon sawdust composted for 28 days, supplemented with $1 \% \mathrm{CaCO}_{3}$ and $10 \%$ wheat bran [40], at the Mushroom Unit of CSIR-Food Research Institute, Accra, Ghana. Cultivation and harvesting were from the period between September and December, 2012. Mushroom fruit bodies were solar-dried at temperature range of $20-40^{\circ} \mathrm{C}$ to a moisture content of about $12 \%$. Dried mushroom parts were cut up to average size of $2 \mathrm{~cm} \times 3 \mathrm{~cm}$ and stored in tight-sealed polythene (P) and polypropylene $(\mathrm{Bx})$ containers at room temperature until needed.

2.3. Irradiation of Mushroom Materials. Forty (40) grams of dried mushrooms were packed into various containers and irradiated at doses of $0,0.5,1,1.5$, and $2 \mathrm{kGy}$ at a dose rate of $1.7 \mathrm{kGy}$ per hour from a cobalt ${ }^{60}$ source (SLL 515, Hungary) in air. Absorbed doses were confirmed using the ethanol-chlorobenzene (ECB) dosimetry system at the Radiation Technology Centre of the Ghana Atomic Energy Commission, Accra, Ghana.

2.4. Preparation of Mushroom Extracts. Mushroom extracts were prepared according to a standard protocol [41]. Prepared mushroom material (10 g) was transferred to dark-colored flasks and mixed with $200 \mathrm{~mL}$ of solvents with different 
polarities (deionized water, methanol, ethanol), respectively, and stored at room temperature. After $24 \mathrm{~h}$, infusions were filtered through Whatman number 1 filter paper and residue was reextracted with equal volume of solvents. After $48 \mathrm{~h}$, the process was repeated. Combined supernatants were evaporated to dryness under vacuum at $30^{\circ} \mathrm{C}$ using a rotary evaporator. The obtained extracts were kept in sterile sample tubes and stored in a refrigerator at $4^{\circ} \mathrm{C}$.

\subsection{Determination of Total Phenolic Contents in the Mush-} room Extracts. The concentration of phenolics in mushroom extracts was determined using spectrophotometric method [42]. Methanolic solution of the extract in the concentration of $1 \mathrm{mg} / \mathrm{mL}$ was used in the analysis. The reaction mixture was prepared by mixing $50 \mathrm{~mL}$ of methanolic solution of extracts, $2.5 \mathrm{~mL}$ of $10 \%$ Folin-Ciocalteu's reagent $(\mathrm{v} / \mathrm{v})$ dissolved in water, and $2.5 \mathrm{~mL} 7.5 \% \mathrm{NaHCO}_{3}$. Blank was concomitantly prepared, containing $50 \mathrm{~mL}$ methanol, $2.5 \mathrm{~mL} 10 \%$ FolinCiocalteu's reagent dissolved in water, and $2.5 \mathrm{~mL}$ of $7.5 \%$ of $\mathrm{NaHCO}_{3}$. The samples were thereafter incubated in a thermostat at $45^{\circ} \mathrm{C}$ for $45 \mathrm{~min}$. The absorbance was determined using spectrophotometer at $\lambda \max =760 \mathrm{~nm}$. The samples were prepared in triplicate for each analysis and the mean value of absorbance was obtained. The same procedure was repeated for the standard solution of gallic acid and the calibration line was constructed. Based on the measured absorbance, the concentration of phenolics was read $\left(\mathrm{mg} \mathrm{mL}^{-1}\right)$ from the calibration line; then the content of phenolics in extracts was expressed in terms of gallic acid equivalent (mg of GA/g of extract).

2.6. Determination of Flavonoid Concentrations in the Mushroom Extracts. The content of flavonoids in the examined mushroom extracts was determined using a modified spectrophotometric method [43]. The sample contained $500 \mathrm{~mL}$ of ethanol solution of the extract in the concentration of $1 \mathrm{mg} / \mathrm{mL}$ and $100 \mathrm{~mL}$ of $10 \% \mathrm{AlCl}_{3}$ solution dissolved in $1500 \mathrm{~mL}$ ethanol. The samples were incubated for an hour at room temperature. The absorbance was determined using spectrophotometer at $\lambda \max =415 \mathrm{~nm}$. The samples were prepared in triplicate for each analysis and the mean value of absorbance was obtained. The same procedure was repeated for the standard solution of $500 \mathrm{~mL}$ of quercetin and $100 \mathrm{~mL}$ of potassium acetate (10\%) and the calibration line was constructed. Based on the measured absorbance, the concentration of flavonoids was read $(\mathrm{mg} / \mathrm{mL})$ on the calibration line; then, the content of flavonoids in extracts was expressed in terms of quercetin equivalent ( $\mathrm{mg}$ of $\mathrm{QE} / \mathrm{g}$ of extract).

2.7. Evaluation of Antioxidant Activity and $I C_{50}$. The ability of the mushroom extract to scavenge DPPH free radicals was assessed by the standard method [44], adopted with suitable modifications [45]. The stock solutions of extracts were prepared in methanol to achieve the concentration of $1 \mathrm{mg} \mathrm{mL}^{-1}$. Dilutions were made to obtain concentrations of $0.01,0.05,0.1,0.15$, and $0.2 \mathrm{mg} \mathrm{mL}^{-1}$. Diluted solutions of sample (200 mL each) were mixed with $3800 \mathrm{~mL}$ of methanolic solution of DPPH. After 30 min incubation in darkness at room temperature $\left(23^{\circ} \mathrm{C}\right)$, the absorbance was recorded at $517 \mathrm{~nm}$. Control sample contained all the reagents except the extract. Percentage inhibition was calculated using (1); the data were presented as mean values \pm standard deviation $(n=2)$. Consider

$$
\% \text { inhibition }=\frac{A \text { of control }-A \text { of sample }}{A \text { of control }} \times 100 \text {. }
$$

$\mathrm{IC}_{50}$ value is the concentration of sample required to scavenge $50 \%$ of DPPH free radical and was calculated by plotting a graph of concentration and \% inhibition. A linear regression was estimated to plot $x-y$ and fit data with a straight line. From linear equation $y=m x+c$, where $y=50$ and $x$ is calculated.

2.8. Statistical Analysis. All experimental measurements were carried out in duplicate and are expressed as average of two analyses \pm standard deviation. The magnitude of correlation between variables was done using a SPSS (Chicago, IL) statistical software package (SPSS for Windows, version XIV, 2004). Significances of differences were conducted with a Duncan's Multiple Range Test (DMRT). Linear regression to correlate between total phenolics and total flavonoid with antioxidant activity was carried out using Excel 2003.

\section{Results and Discussions}

3.1. The Total Phenolic Content. The major antioxidants found in mushrooms are phenolic compounds while other potential antioxidants such as ascorbic acid, $\beta$-carotene, lycopene, and $\gamma$-tocopherol have only been found in very small amounts [46-48]. Phenolics are important constituents with scavenging ability due to their hydroxyl groups and hence may contribute directly to the antioxidative action [49]. Irradiation dose of $0.5 \mathrm{kGy}$ apparently influenced the production of phenolics and caused a significantly $(P<$ 0.05 ) higher contents with aqueous and ethanol extracts. The total phenolic content was expressed in terms of gallic acid equivalent in milligram $(\mathrm{mg})$ per gram of dry material. The calibration curve (the standard curve: $y=1.225 x-0.003, r^{2}=$ 0.988 ) was used to determine total phenolic content as shown in Figure 1. The total phenolic content of the various extracts was compiled in Table 1. Generally high values of antioxidant activity were recorded for aqueous $1.96 \pm 0.05-10.96 \pm$ $1.7 \mathrm{mgGAE} / \mathrm{g}$. Methanol and ethanol extracts ranged from $0.56 \pm 0.01-4.81 \pm 0.4 \mathrm{mgGAE} / \mathrm{g}$ and $1.32 \pm 0.02-2.36 \pm$ $0.2 \mathrm{mgGAE} / \mathrm{g}$, respectively. Irradiation dose of $0.5 \mathrm{kGy}$ produced greatest amounts of phenols for all the extracts while $2 \mathrm{kGy}$ recorded least for the extracts. In terms of packaging material suitability, there was no significant $(P>0.05)$ difference between polythene and polypropylene. The values were within the range of total phenolic content of antioxidant activity of $15.38 \pm 0.56-16.80 \pm 0.15 \mathrm{gGE} / 100 \mathrm{~g}$ dry weight of gamma irradiated pomegranate (Punica granatum) peels recorded by [50]. The phenol contents of $P$. ostreatus are also within the same range as that of some commonly consumed green leafy vegetables in W. Africa [51, 52]. 
TABLE 1: Total phenolic content (mgGAE/g) of dried and irradiated mushrooms of polythene $(\mathrm{P})$ and polypropylene $(\mathrm{Bx})$ packs from 3 extracts.

\begin{tabular}{lccc}
\hline Treatment & $\begin{array}{c}\text { Aqueous } \\
(\mathrm{mgGAE} / \mathrm{g})\end{array}$ & $\begin{array}{c}\text { Extract } \\
\text { Ethanol } \\
(\mathrm{mgGAE} / \mathrm{g})\end{array}$ & $\begin{array}{c}\text { Methanol } \\
(\mathrm{mgGAE} / \mathrm{g})\end{array}$ \\
\hline P 0 & $3.84 \pm 0.4^{\mathrm{a}}$ & $2.0 \pm 0.1^{\mathrm{b}}$ & $2.4 \pm 0.1^{\mathrm{b}}$ \\
P 0.5 & $5.0 \pm 0.3^{\mathrm{ab}}$ & $2.36 \pm 0.2^{\mathrm{bc}}$ & $2.36 \pm 0.2^{\mathrm{b}}$ \\
P 1 & $4.63 \pm 0.3^{\mathrm{a}}$ & $1.54 \pm 0.18^{\mathrm{b}}$ & $4.81 \pm 0.4^{\mathrm{c}}$ \\
P 1.5 & $2.78 \pm 0.1^{\mathrm{a}}$ & $1.32 \pm 0.02^{\mathrm{a}}$ & $2.83 \pm 0.1^{\mathrm{b}}$ \\
P 2 & $1.96 \pm 0.05^{\mathrm{a}}$ & $1.32 \pm 0.02^{\mathrm{a}}$ & $1.96 \pm 0.05^{\mathrm{b}}$ \\
Bx 0 & $2.54 \pm 0.1^{\mathrm{a}}$ & $1.32 \pm 0.02^{\mathrm{a}}$ & $1.93 \pm 0.05^{\mathrm{b}}$ \\
Bx 0.5 & $4.46 \pm 0.3^{\mathrm{a}}$ & $1.96 \pm 0.05^{\mathrm{bc}}$ & $2.31 \pm 0.2^{\mathrm{b}}$ \\
Bx 1 & $10.96 \pm 1.7^{\mathrm{b}}$ & $1.53 \pm 0.04^{\mathrm{b}}$ & $1.35 \pm 0.03^{\mathrm{a}}$ \\
Bx 1.5 & $4.46 \pm 0.8^{\mathrm{a}}$ & $1.89 \pm 0.07^{\mathrm{bc}}$ & $0.56 \pm 0.01^{\mathrm{a}}$ \\
Bx 2 & $2.5 \pm 0.2^{\mathrm{a}}$ & $1.76 \pm 0.05^{\mathrm{b}}$ & $1.4 \pm 0.03^{\mathrm{a}}$ \\
\hline
\end{tabular}

Means with same letters in a column are not significantly different $(P>0.05)$.
TABLE 2: Flavonoid content (mgQE/g) of dried and irradiated mushrooms of polythene $(\mathrm{P})$ and polypropylene $(\mathrm{Bx})$ packs from 3 extracts.

\begin{tabular}{lccc}
\hline Treatments & $\begin{array}{c}\text { Aqueous } \\
(\mathrm{mgQE} / \mathrm{g})\end{array}$ & $\begin{array}{c}\text { Extracts } \\
\text { Ethanol }(\mathrm{mgQE} / \mathrm{g})\end{array}$ & $\begin{array}{c}\text { Methanol } \\
(\mathrm{mgQE} / \mathrm{g})\end{array}$ \\
\hline P 0 & $7.67 \pm 0.8^{\mathrm{a}}$ & $4.25 \pm 0.2^{\mathrm{ab}}$ & $3.93 \pm 0.2^{\mathrm{a}}$ \\
P 0.5 & $8.92 \pm 0.6^{\mathrm{a}}$ & $7.27 \pm 0.4^{\mathrm{b}}$ & $3.81 \pm 0.2^{\mathrm{a}}$ \\
P 1 & $8.07 \pm 0.7^{\mathrm{a}}$ & $5.58 \pm 0.2^{\mathrm{b}}$ & $4.61 \pm 0.4^{\mathrm{a}}$ \\
P 1.5 & $3.7 \pm 0.2^{\mathrm{ab}}$ & $1.64 \pm 0.05^{\mathrm{a}}$ & $3.51 \pm 0.2^{\mathrm{a}}$ \\
P 2 & $6.73 \pm 0.5^{\mathrm{a}}$ & $7.88 \pm 0.4^{\mathrm{c}}$ & $2.88 \pm 0.1^{\mathrm{a}}$ \\
Bx 0 & $3.09 \pm 0.2^{\mathrm{ab}}$ & $4.73 \pm 0.2^{\mathrm{ab}}$ & $4.18 \pm 0.2^{\mathrm{a}}$ \\
Bx 0.5 & $8.75 \pm 0.8^{\mathrm{a}}$ & $7.86 \pm 0.4^{\mathrm{b}}$ & $5.37 \pm 0.5^{\mathrm{a}}$ \\
Bx 1 & $7.92 \pm 0.6^{\mathrm{a}}$ & $4.42 \pm 0.2^{\mathrm{ab}}$ & $2.50 \pm 0.2^{\mathrm{a}}$ \\
Bx 1.5 & $7.92 \pm 0.6^{\mathrm{a}}$ & $6.29 \pm 0.4^{\mathrm{b}}$ & $2.0 \pm 0.1^{\mathrm{a}}$ \\
Bx 2 & $3.46 \pm 0.3^{\mathrm{ab}}$ & $5.88 \pm 0.3^{\mathrm{b}}$ & $4.9 \pm 0.4^{\mathrm{a}}$ \\
\hline
\end{tabular}

Means with same letters in a column are not significantly different $(P>0.05)$.

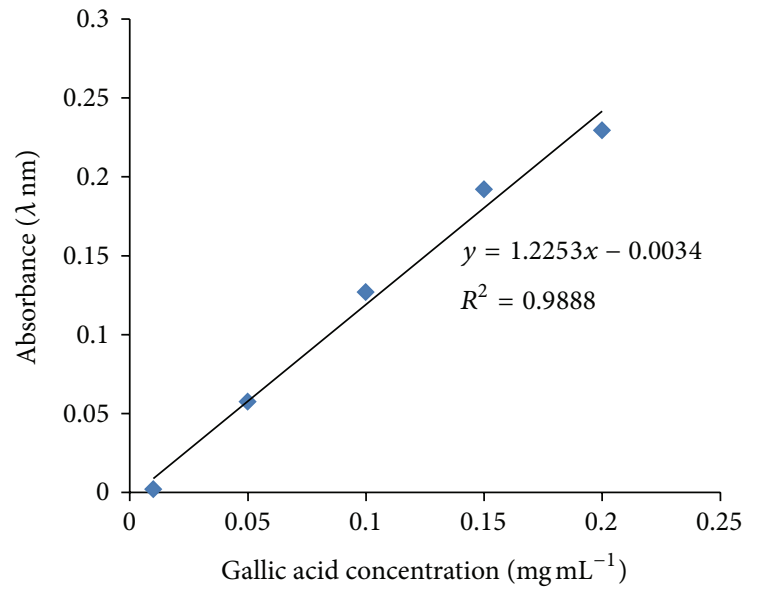

FIGURE 1: Calibration curve for the determination of total phenolics.

3.2. Flavonoid Content. Flavonoids are a class of secondary plant metabolites with significant antioxidant and chelating properties. Antioxidant activity of flavonoids depends on the structure and substitution pattern of hydroxyl groups [53]. The concentration of flavonoids in plant extracts depends on the polarity of solvents used in the extract preparation [54]. The flavonoid content was expressed in terms of quercetin equivalent in milligrams per gram of dry material. The calibration curve (the standard curve equation: $y=$ $\left.0.005 x+0.00, r^{2}=0.986\right)$ was used to determine flavonoid content as shown in Figure 2. The total flavonoid content of the various extracts was compiled in Table 2. Results of flavonoid content are presented in Table 2. There were significant differences $(P \leq 0.05)$ between flavonoid contents of doses and solvent extracts. The extraction concentrations followed a descending order of aqueous $>$ methanol $>$ ethanol. Extraction with aqueous ranged 3.09 $\pm 0.2-8.42 \pm$ $0.6 \mathrm{mgQE} / \mathrm{g}$, methanol ranged $2.0 \pm 0.1-4.90 \pm 0.4 \mathrm{mgQE} / \mathrm{g}$, and ethanol $1.64 \pm 0.05-7.88 \pm 0.4 \mathrm{mgQE} / \mathrm{g}$. There were significant differences $(P<0.05)$ recorded for aqueous and ethanol extracts. However, no significant differences $(P>$ 0.05 ) were recorded for methanol extracts. Irradiation dose of $0.5 \mathrm{kGy}$ recorded greatest amounts of flavonoids in general for all the extracts while $0,0.5$, and $2 \mathrm{kGy}$ recorded the least flavonoids. In terms of packaging material suitability, there was no significant $(P>0.05)$ difference between polythene and polypropylene. The flavonoid concentrations of $P$. ostreatus were found to be lower than works of some authors [55-57]. Nonetheless, the values recorded were higher than and were contrary to works of $[57,58]$ who found no flavonoids in P. ostreatus as they investigated the comparative phytochemical, antimicrobial, and antioxidant properties and also, contents of vitamins, mineral elements, and some phenolic compounds in cultivated mushrooms, respectively.

3.3. DPPH Free Radical Scavenging Activity. Free radical scavenging is one of the mechanisms in inhibiting lipid oxidation commonly used to estimate antioxidant activity $[59,60]$. The extraction pattern was consistent with total phenolic and flavonoid. The DPPH free radical scavenging activity was expressed in terms of gallic acid equivalent in milligrams(mg) per gram(g) of dry material. The calibration curve (the standard curve: $y=-3.309 x+0.7374, r^{2}=$ 0.8507 ) as shown in Figure 3. Extraction with aqueous ranged $9.62 \pm 0.10-12.5 \pm 0.02 \mathrm{mgGAE} / \mathrm{g}$, methanol ranged $6.73 \pm$ $0.04-9.42 \pm 0.13 \mathrm{mgGAE} / \mathrm{g}$, and ethanol $1.89 \pm 0.05-3.65 \pm$ $0.22 \mathrm{mgGAE} / \mathrm{g}$ (Table 3 ). There were significant differences $(P<0.05)$ recorded between extracts of aqueous and ethanol. Methanol extracts, however, recorded no significant differences. Packaging materials were not significantly different.

3.4. Percentage (\%) Inhibition of DPPH and $I C_{50}$. The half maximal inhibitory concentration $\left(\mathrm{IC}_{50}\right)$ is a measure of the 


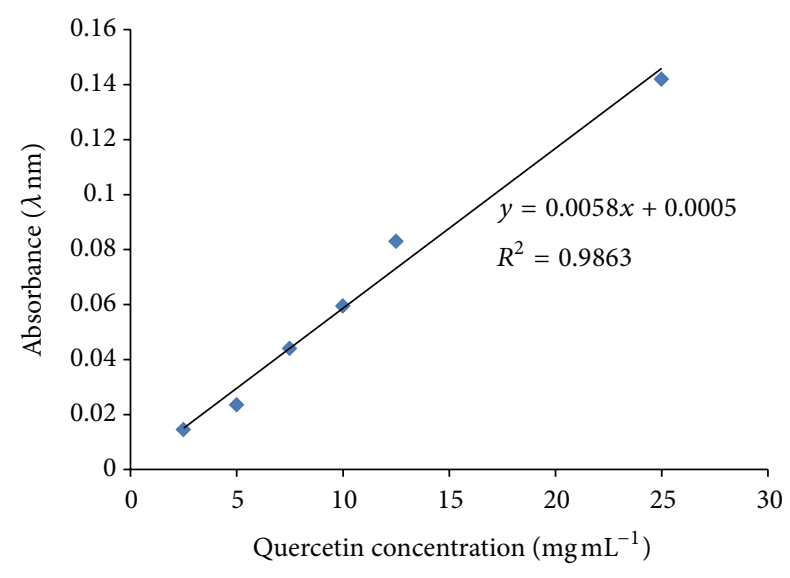

FIGURE 2: Calibration curve for the determination of flavonoids.

TABLE 3: DPPH free radical scavenging activity of dried and irradiated mushrooms of polythene $(\mathrm{P})$ and polypropylene $(\mathrm{Bx})$ packs from 3 extracts.

\begin{tabular}{lccc}
\hline Treatments & $\begin{array}{c}\text { Aqueous } \\
(\mathrm{mgGAE} / \mathrm{g})\end{array}$ & $\begin{array}{c}\text { Extracts } \\
\text { Ethanol } \\
(\mathrm{mgGAE} / \mathrm{g})\end{array}$ & $\begin{array}{c}\text { Methanol } \\
(\mathrm{mgGAE} / \mathrm{g})\end{array}$ \\
\hline P 0 & $0.07 \pm 0.01^{\mathrm{ab}}$ & $0.10 \pm 0.03^{\mathrm{bc}}$ & $0.11 \pm 0.03^{\mathrm{a}}$ \\
P 0.5 & $0.10 \pm 0.03^{\mathrm{b}}$ & $0.11 \pm 0.03^{\mathrm{c}}$ & $0.13 \pm 0.04^{\mathrm{a}}$ \\
P 1 & $0.12 \pm 0.05^{\mathrm{b}}$ & $0.09 \pm 0.02^{\mathrm{bc}}$ & $0.13 \pm 0.04^{\mathrm{a}}$ \\
P 1.5 & $0.09 \pm 0.02^{\mathrm{b}}$ & $0.09 \pm 0.02^{\mathrm{bc}}$ & $0.10 \pm 0.03^{\mathrm{a}}$ \\
P 2 & $0.09 \pm 0.02^{\mathrm{b}}$ & $0.08 \pm 0.02^{\mathrm{b}}$ & $0.11 \pm 0.03^{\mathrm{a}}$ \\
Bx 0 & $0.10 \pm 0.03^{\mathrm{b}}$ & $0.09 \pm 0.02^{\mathrm{bc}}$ & $0.10 \pm 0.03^{\mathrm{a}}$ \\
Bx 0.5 & $0.08 \pm 0.02^{\mathrm{b}}$ & $0.11 \pm 0.03^{\mathrm{c}}$ & $0.11 \pm 0.03^{\mathrm{a}}$ \\
Bx 1 & $0.11 \pm 0.03^{\mathrm{b}}$ & $0.07 \pm 0.01^{\mathrm{a}}$ & $0.09 \pm 0.02^{\mathrm{a}}$ \\
Bx 1.5 & $0.11 \pm 0.03^{\mathrm{b}}$ & $0.09 \pm 0.02^{\mathrm{bc}}$ & $0.09 \pm 0.02^{\mathrm{a}}$ \\
Bx 2 & $0.09 \pm 0.02^{\mathrm{b}}$ & $0.09 \pm 0.02^{\mathrm{bc}}$ & $0.10 \pm 0.03^{\mathrm{a}}$ \\
\hline
\end{tabular}

Means with same letters in a column are not significantly different $(P>0.05)$.

effectiveness of a compound in inhibiting a biological or biochemical function. The antioxidant activity with $\mathrm{IC}_{50}<$ 10 micro grams $/ \mathrm{mL}$ value corresponds to good antioxidant activity and is included in the category of powerful antioxidants class [61-63]. The process of free radicals reduction is achieved through the mechanism of hydrogen donation from antioxidants [64]. Free radicals used are synthetic DPPH that reacts with an antioxidant compound through the donation of electrons from an antioxidant compound to get a pair of electrons. DPPH radical compound deep purple would fade to yellow if it is reduced by antioxidants into nonradical DPPH [62], when the free electron of DPPH radical has been paired with electrons from traps compounds (antioxidants) that would reduce $\mathrm{DPPH}$ radical (DPPH-H) and form stable compounds that are DPP Hydrazine [63].

Aqueous extraction ranged 8.24 \pm 0.03-11.6 \pm $0.05 \% \mathrm{mgGAE} / \mathrm{g}$, methanol ranged $8.79 \pm 0.06-13.03 \pm$ $0.04 \% \mathrm{mgGAE} / \mathrm{g}$, and ethanol ranged $8.31 \pm 0.04-10.81 \pm$

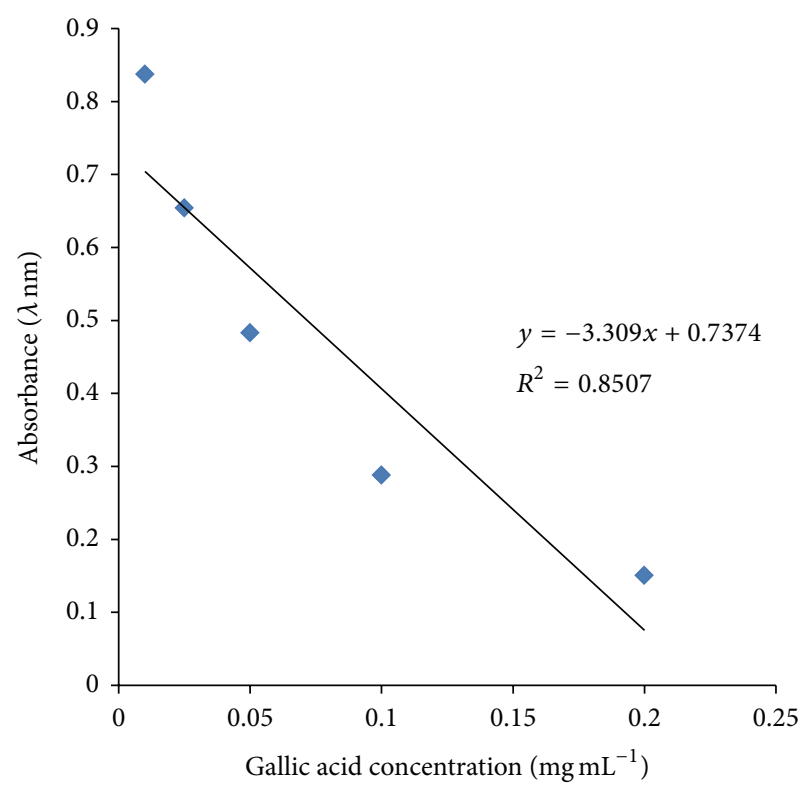

FIGURE 3: Calibration curve for the determination of DPPH free radical scavenging activity.

$0.25 \% \mathrm{mgGAE} / \mathrm{g}$ (Table 4 ). In terms of packaging material suitability, there was no significant $(P>0.05)$ difference between polythene and polypropylene. Figure 2 shows the amount of each extract needed for $50 \%$ inhibition $\left(\mathrm{IC}_{50}\right)$. $\mathrm{IC}_{50} \mathrm{mg} \mathrm{mL}^{-1}$ of the extracts was in the order aqueous < methanol < ethanol and corresponded to $0.064,1.03$, and 1.03 , respectively. $\mathrm{IC}_{50}$ of the standard compound quercetin was $0.01 \mathrm{mg} \mathrm{mL}^{-1}$. The highest radical scavenging activity was shown by aqueous extract with $\mathrm{IC}_{50}=0.064 \mathrm{mg} \mathrm{mL}^{-1}$ which is lower than that of quercetin $(P<0.05)$. All of the extracts showed significant difference $(P \leq 0.05)$ from the standard compound (Figure 4). The high contents of phenolic compounds and significant linear correlation between the values of the concentration of phenolic compounds and antioxidant activity indicated that these compounds in mushrooms contribute to the strong antioxidant activity.

\section{Conclusions}

Although the interaction of gamma radiation and polythene and/or polypropylene packaging materials caused some significant differences $(P \leq 0.05)$ in total phenolic content, flavonoids, and antioxidant activity which eventually cause oxidative damage and impair flavor in food, there was no apparent difference between the packaging materials (Tables 1,2, and 3). However, the action of effective and radiostable natural antioxidants may prevent chemical oxidation of biomolecules in irradiated food. Gamma radiation had no adverse effect on the dried mushrooms. It enhanced shelf-life as it was able to prevent insect and pest infestation. 
TABLE 4: Percentage inhibition (\%) of DPPH in dried and irradiated mushrooms in storage packages.

\begin{tabular}{lccc}
\hline Treatments & $\begin{array}{c}\text { Extracts } \\
\text { (mgGeous (\%) }\end{array}$ & $\begin{array}{c}\text { Ethanol (\%) } \\
(\text { mgGAE/g) }\end{array}$ & $\begin{array}{c}\text { Methanol (\%) } \\
(\text { mgGAE/g) }\end{array}$ \\
\hline P 0 & $7.02 \pm 0.10^{\mathrm{a}}$ & $10.06 \pm 0.13^{\mathrm{bc}}$ & $10.9 \pm 0.26^{\mathrm{b}}$ \\
P 0.5 & $9.65 \pm 0.13^{\mathrm{bc}}$ & $10.47 \pm 0.24^{\mathrm{c}}$ & $13.03 \pm 0.04^{\mathrm{b}}$ \\
P 1 & $11.6 \pm 0.05^{\mathrm{d}}$ & $9.36 \pm 0.12^{\mathrm{bc}}$ & $12.82 \pm 0.03^{\mathrm{b}}$ \\
P 1.5 & $9.46 \pm 0.13^{\mathrm{bc}}$ & $9.36 \pm 0.12^{\mathrm{bc}}$ & $10.30 \pm 0.27^{\mathrm{b}}$ \\
P 2 & $9.26 \pm 0.16^{\mathrm{bc}}$ & $8.31 \pm 0.04^{\mathrm{a}}$ & $10.60 \pm 0.3^{\mathrm{b}}$ \\
Bx 0 & $9.65 \pm 0.13^{\mathrm{bc}}$ & $8.95 \pm 0.05^{\mathrm{bc}}$ & $10.40 \pm 0.3^{\mathrm{b}}$ \\
Bx 0.5 & $8.24 \pm 0.03^{\mathrm{a}}$ & $10.81 \pm 0.25^{\mathrm{d}}$ & $11.21 \pm 0.04^{\mathrm{b}}$ \\
Bx 1 & $11.12 \pm 0.05^{\mathrm{c}}$ & $7.44 \pm 0.16^{\mathrm{a}}$ & $9.09 \pm 0.12^{\mathrm{a}}$ \\
Bx 1.5 & $11.27 \pm 0.02^{\mathrm{c}}$ & $8.84 \pm 0.05^{\mathrm{bc}}$ & $8.79 \pm 0.06^{\mathrm{a}}$ \\
Bx 2 & $9.37 \pm 0.12^{\mathrm{bc}}$ & $9.06 \pm 0.11^{\mathrm{bc}}$ & $10.30 \pm 0.3^{\mathrm{b}}$ \\
\hline
\end{tabular}

Means with same letters in a column are not significantly different $(P>0.05)$.

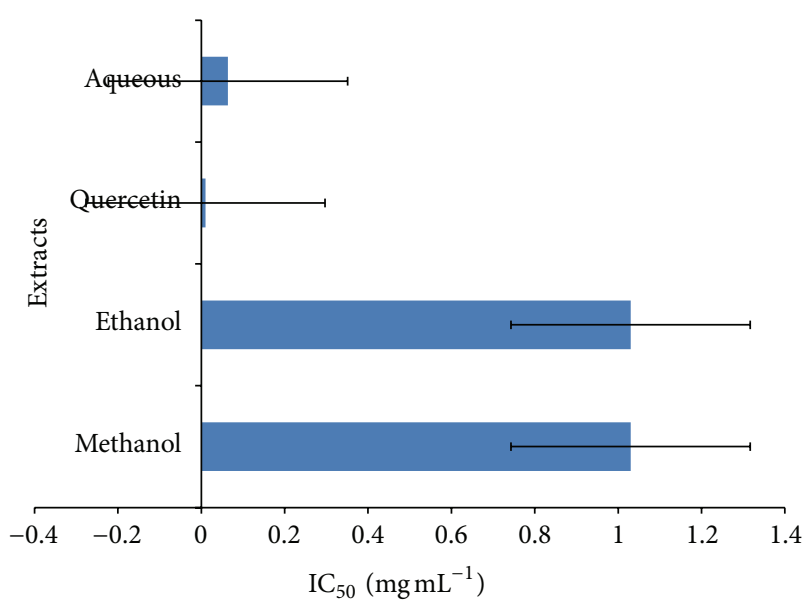

Figure 4: $\mathrm{IC}_{50}\left(\mathrm{mg} \mathrm{mL}^{-1}\right)$ values of mushroom extracts for free radical scavenging activity by DPPH radical. (1) Methanol, (2) ethanol, (3) quercetin (standard), and (4) aqueous.

\section{Conflict of Interests}

The authors declare that there is no conflict of interests regarding the publication of this paper.

\section{Acknowledgment}

The authors are grateful to the staff and laboratory technicians of Applied Radiation Biology Centre (ARBC) of the Ghana Atomic Energy Commission, Accra.

\section{References}

[1] D. Tura and K. Robards, "Sample handling strategies for the determination of biophenols in food and plants," Journal of Chromatography A, vol. 975, no. 1, pp. 71-93, 2002.

[2] H. L. Madsen and G. Bertelsen, "Spices as antioxidants," Trends in Food Science and Technology, vol. 6, no. 8, pp. 271-277, 1995.
[3] J. B. Harborne, Phytochemical Methods, Springer, London, UK, 1998.

[4] M. Daglia, "Polyphenols as antimicrobial agents," Current Opinion in Biotechnology, vol. 23, no. 2, pp. 174-181, 2012.

[5] I. Naasani, F. Oh-hashi, T. Oh-hara et al., "Blocking telomerase by dietary polyphenols is a major mechanism for limiting the growth of human cancer cells in vitro and in vivo," Cancer Research, vol. 63, no. 4, pp. 824-830, 2003.

[6] T. Hussain, S. Gupta, V. M. Adhami, and H. Mukhtar, "Green tea constituent epigallocatechin-3-gallate selectively inhibits COX-2 without affecting COX-1 expression in human prostate carcinoma cells," International Journal of Cancer, vol. 113, no. 4, pp. 660-669, 2005.

[7] K. A. O’Leary, S. de Pascual-Tereasa, P. W. Needs, Y. Bao, N. M. O'Brien, and G. Williamson, "Effect of flavonoids and Vitamin E on cyclooxygenase-2 (COX-2) transcription," Mutation Research, vol. 551, no. 1-2, pp. 245-254, 2004.

[8] C. D. Sadik, H. Sies, and T. Schewe, "Inhibition of 15lipoxygenases by flavonoids: structure-activity relations and mode of action," Biochemical Pharmacology, vol. 65, no. 5, pp. 773-781, 2003.

[9] T. Schewe, C. Sadik, L. Klotz, T. Yoshimoto, H. Kühn, and H. Sies, "Polyphenols of cocoa: inhibition of mammalian 15lipoxygenase," The Journal of Biological Chemistry, vol. 382, no. 12, pp. 1687-1696, 2001.

[10] A. T. Kong, R. Yu, C. Chen, S. Mandlekar, and T. Primiano, "Signal transduction events elicited by natural products: role of MAPK and caspase pathways in homeostatic response and induction of apoptosis," Archives of Pharmacal Research, vol. 23, no. 1, pp. 1-16, 2000.

[11] J. P. Spencer, C. Rice-Evans, and R. J. Williams, "Modulation of pro-survival Akt/protein kinase B and ERK1/2 signaling cascades by quercetin and its in vivo metabolites underlie their action on neuronal viability," The Journal of Biological Chemistry, vol. 278, no. 37, pp. 34783-34793, 2003.

[12] S. Wiseman, T. Mulder, and A. Rietveld, "Tea flavonoids: bioavailability in vivo and effects on cell signaling pathways in vitro," Antioxidants and Redox Signaling, vol. 3, no. 6, pp. 10091021, 2001.

[13] S. Wei and L. J. L. D. van Griensven, "Pro- and antioxidative properties of medicinal mushroom extracts," International Journal of Medicinal Mushrooms, vol. 10, no. 4, pp. 315-324, 2008.

[14] N. J. Dubost, B. Ou, and R. B. Beelman, "Quantification of polyphenols and ergothioneine in cultivated mushrooms and correlation to total antioxidant capacity," Food Chemistry, vol. 105, no. 2, pp. 727-735, 2007.

[15] J. Mau, S. Tsai, Y. Tseng, and S. Huang, "Antioxidant properties of hot water extracts from Ganoderma tsugae Murrill," LWT Food Science and Technology, vol. 38, no. 6, pp. 589-597, 2005.

[16] P. Kalač, "Chemical composition and nutritional value of European species of wild growing mushrooms: a review," Food Chemistry, vol. 113, no. 1, pp. 9-16, 2009.

[17] J. N. K. Kortei, Determination of optimal growth and yield parameters of Pleurotusostreatus grown on composted cassava peel based formulations [M.S. thesis], Department of Biochemistry and Biotechnology, Kwame Nkrumah University of Science and Technology, Kumasi, Ghana, 2008.

[18] J. N. K. Kortei, Growing Oyster Mushrooms (Pleurotus ostreatus) on Composted Agrowastes: An Efficient Way of Utilizing Lignocellulosic Materials, Lambert Academic Publishing, Saarbrücken, Germany, 2011. 
[19] I. C. F. R. Ferreira, J. A. Vaz, M. H. Vasconcelos, and A. Martins, "Compounds from wild mushrooms with antitumor potential," Anti-Cancer Agents in Medicinal Chemistry, vol. 10, no. 5, pp. 424-436, 2010.

[20] I. C. F. R. Ferreira, L. Barros, and R. M. V. Abreu, "Antioxidants in wild mushrooms," Current Medicinal Chemistry, vol. 16, no. 12, pp. 1543-1560, 2009.

[21] V. Shlyakhovenko, V. Kosak, and S. Olishevsky, "Application of DNA from mushroom Pleurotus ostreatus for cancer biotherapy: a pilot study," Experimental Oncology, vol. 28, no. 2, pp. 132-135, 2006.

[22] T. Ghosh, T. K. Maity, P. Sengupta, D. K. Dash, and A. Bose, "Antidiabetic and in vivo antioxidant activity of ethanolic extract of Bacopa monnieri Linn. Aerial parts: a possible mechanism of action," Iranian Journal of Pharmaceutical Research, vol. 7, no. 1, pp. 61-68, 2008.

[23] B. I. Ognjanović, S. D. Marković, S. Z. Pavlović, R. V. Žikić, A. Š. Štajn, and Z. S. Saičić, "Effect of chronic cadmium exposure on antioxidant defense system in some tissues of rats: protective effect of selenium," Physiological Research, vol. 57, no. 3, pp. 403411, 2008.

[24] L. Barros, M. Dueñas, I. C. F. R. Ferreira, P. Baptista, and C. Santos-Buelga, "Phenolic acids determination by HPLCDAD-ESI/MS in sixteen different Portuguese wild mushrooms species," Food and Chemical Toxicology, vol. 47, no. 6, pp. 10761079, 2009.

[25] B. Queirós, J. C. M. Barreira, A. C. Sarmento, and I. C. F. R. Ferreira, "In search of synergistic effects in antioxidant capacity of combined edible mushrooms," International Journal of Food Sciences and Nutrition, vol. 60, no. 6, pp. 160-172, 2009.

[26] A. Rohman, S. Riyanto, N. Yuniarti, W. R. Saputra, R. Utami, and W. Mulatsih, "Antioxidant activity, total phenolic, and total flavaonoid of extracts and fractions of red fruit (Pandanus conoideus Lam)," International Food Research Journal, vol. 17, no. 1, pp. 97-106, 2010.

[27] W. Zheng and S. Y. Wang, "Antioxidant activity and phenolic compounds in selected herbs," Journal of Agricultural and Food Chemistry, vol. 49, no. 11, pp. 5165-5170, 2001.

[28] A. Błaszczyk and J. Skolimowski, "Preparation of ethoxyquin salts and their genotoxic and antioxidant effects on human lymphocytes," Arkivoc, vol. 2007, no. 6, pp. 217-229, 2007.

[29] F. Pourmorad, S. J. Hosseinimehr, and N. Shahabimajd, "Antioxidant activity, phenol and flavonoid contents of some selected Iranian medicinal plants," African Journal of Biotechnology, vol. 5, no. 11, pp. 1142-1145, 2006.

[30] I. I. Koleva, T. A. van Beek, J. P. H. Linssen, A. de Groot, and L. N. Evstatieva, "Screening of plant extracts for antioxidant activity: a comparative study on three testing methods," Phytochemical Analysis, vol. 13, no. 1, pp. 8-17, 2002.

[31] M. Atanassova, S. Georgieva, and K. Ivancheva, "Total phenolic and total flavonoid contents, antioxidant capacity and biological contaminants in medicinal herbs," Journal of the University of Chemical Technology and Metallurgy, vol. 46, no. 1, pp. 81-88, 2011.

[32] D. Kozlowski, P. Marsal, M. Steel et al., "Theoretical investigation of the formation of a new series of antioxidant depsides from the radiolysis of flavonoid compounds," Radiation Research, vol. 168, no. 2, pp. 243-252, 2007.

[33] T. Tokura, N. Nakano, T. Ito et al., "Inhibitory effect of polyphenol-enriched apple extracts on mast cell degranulation in vitro targeting the binding between IgE and FceRI," Bioscience, Biotechnology and Biochemistry, vol. 69, no. 10, pp. 19741977, 2005.

[34] T. Enomoto, Y. Nagasako-Akazome, T. Kanda, M. Ikeda, and Y. Dake, "Clinical effects of apple polyphenols on persistent allergic rhinitis: a randomized double-blind placebo-controlled parallel arm study," Journal of Investigational Allergology and Clinical Immunology, vol. 16, no. 5, pp. 283-289, 2006.

[35] H. Akiyama, J. Sakushima, S. Taniuchi et al., "Antiallergic effect of apple polyphenols on the allergic model mouse," Biological and Pharmaceutical Bulletin, vol. 23, no. 11, pp. 1370-1373, 2000.

[36] L. Letenneur, C. Proust-Lima, A. Le Gouge, J. F. Dartigues, and P. Barberger-Gateau, "Flavonoid intake and cognitive decline over a 10-year period," The American Journal of Epidemiology, vol. 165, no. 12, pp. 1364-1371, 2007.

[37] M. J. Rodríguez Vaquero, P. A. Aredes Fernández, M. C. Manca de Nadra, and A. M. Strasser de Saad, "Phenolic compound combinations on Escherichia coli viability in a meat system," Journal of Agricultural and Food Chemistry, vol. 58, no. 10, pp. 6048-6052, 2010.

[38] P. Jayaraman, M. K. Sakharkar, C. S. Lim, T. H. Tang, and K. R. Sakharkar, "Activity and interactions of antibiotic and phytochemical combinations against pseudomonas aeruginosa in vitro," International Journal of Biological Sciences, vol. 6, no. 6, pp. 556-568, 2010.

[39] M. J. Saavedra, A. Borges, C. Dias et al., "Antimicrobial activity of phenolics and glucosinolate hydrolysis products and their synergy with streptomycin against pathogenic bacteria," Medicinal Chemistry, vol. 6, no. 3, pp. 174-183, 2010.

[40] M. Obodai, J. Cleland-Okine, and K. A. Vowotor, "Comparative study on the growth and yield of Pleurotus ostreatus mushroom on different lignocellulosic by-products," Journal of Industrial Microbiology and Biotechnology, vol. 30, no. 3, pp. 146-149, 2003.

[41] M. S. Stankovic, "Total phenolic content, flavonoid concentration and antioxidant activity of Marrubium peregrinum L. extracts," Kragujevac Journal of Science, vol. 33, pp. 63-72, 2011.

[42] V. L. Singleton, R. Orthofer, and R. M. Lamuela-Raventós, "Analysis of total phenols and other oxidation substrates and antioxidants by means of folin-ciocalteu reagent," Methods in Enzymology, vol. 299, pp. 152-178, 1999.

[43] C. Quettier-Deleu, B. Gressier, J. Vasseur et al., "Phenolic compounds and antioxidant activities of buckwheat (Fagopyrum esculentum Moench) hulls and flour," Journal of Ethnopharmacology, vol. 72, no. 1-2, pp. 35-42, 2000.

[44] T. Takao, F. Kitatani, N. Watanabe, A. Yagi, and K. Sakata, "A simple screening method for antioxidants and isolation of several antioxidants produced by marine bacteria from fish and shellfish," Bioscience, Biotechnology and Biochemistry, vol. 58, no. 10, pp. 1780-1783, 1994.

[45] Y. Kumarasamy, M. Byres, P. J. Cox, M. Jaspars, L. Nahar, and S. D. Sarker, "Screening seeds of some Scottish plants for free radical scavenging activity," Phytotherapy Research, vol. 21, no. 7, pp. 615-621, 2007.

[46] L. Barros, S. Falcão, P. Baptista, C. Freire, M. Vilas-Boas, and I. C. F. R. Ferreira, "Antioxidant activity of Agaricus sp. mushrooms by chemical, biochemical and electrochemical assays," Food Chemistry, vol. 111, no. 1, pp. 61-66, 2008.

[47] L. Barros, M. Ferreira, B. Queirós, I. C. F. R. Ferreira, and P. Baptista, "Total phenols, ascorbic acid, $\beta$-carotene and lycopene in Portuguese wild edible mushrooms and their antioxidant activities," Food Chemistry, vol. 103, no. 2, pp. 413-419, 2007. 
[48] J. Yang, H. Lin, and J. Mau, "Antioxidant properties of several commercial mushrooms," Food Chemistry, vol. 77, no. 2, pp. 229-235, 2002.

[49] C. W. Choi, S. C. Kim, S. S. Hwang et al., "Antioxidant activity and free radical scavenging capacity between Korean medicinal plants and flavonoids by assay-guided comparison," Plant Science, vol. 163, no. 6, pp. 1161-1168, 2002.

[50] S. S. Lele, A. B. Mali, and K. Khedkar, "Effect of gamma irradiation on total phenolic content and in vitro antioxidant activity of pomegranate (Punica Granatum L.) peels," Food and Nutrition Sciences, vol. 2, pp. 428-433, 2011.

[51] F. L. Ola and G. Oboh, "Food value of two commonly found Nigerian edible Mushrooms (Termitomycetes striatus and Termitomycetes robustus)," Journal of Technoscience, vol. 4, pp. 1-3, 2000.

[52] F. L. Ola and G. Oboh, "Nutrient distribution and zinc bioavailability estimation in some tropical edible mushrooms," Food/Nahrung, vol. 45, no. 1, pp. 67-68, 2001.

[53] F. Sharififar, G. Dehghn-Nudeh, and M. Mirtajaldini, "Major flavonoids with antioxidant activity from Teucrium polium L.," Food Chemistry, vol. 112, no. 4, pp. 885-888, 2009.

[54] G. Min and L. Chun-Zhao, "Comparison of techniques for the extraction of flavonoids from cultured cells of Saussurea medusa Maxim," World Journal of Microbiology and Biotechnology, vol. 21, pp. 1461-1463, 2005.

[55] A. M. Fernandes de Oliveira, L. S. Pinheiro, C. K. S. Pereira et al., "Total phenolic content and antioxidant activity of some Malvacaea family species," Antioxidants, vol. 1, pp. 33-43, 2012.

[56] A. Eghdami and F. Sadeghi, "Determination of total phenolic and flavonoid contents in methanolic and aqueous extract of Achillea millefollium," Organic Chemistry Journal, vol. 2, pp. 8184, 2010.

[57] B. A. Iwalokun, U. A. Usen, A. A. Otunba, and D. K. Olukoya, "Comparative phytochemical evaluation, antimicrobial and antioxidant properties of Pleurotus ostreatus," African Journal of Biotechnology, vol. 6, no. 15, pp. 1732-1739, 2007.

[58] P. Mattila, K. Könkö, M. Eurola et al., "Contents of vitamins, mineral elements, and some phenolic compounds in cultivated mushrooms," Journal of Agricultural and Food Chemistry, vol. 49, no. 5, pp. 2343-2348, 2001.

[59] K. O. Interaprichet and P. Chirinang, "Amino acids antioxidant properties of the oyster mushrooms, Pleurotus ostreatus and Pleurotus sajor-caju," ScienceAsia, vol. 35, pp. 326-331, 2009.

[60] J. Y. Wong and F. Y. Chye, "Antioxidant properties of selected tropical wild edible mushrooms," Journal of Food Composition and Analysis, vol. 22, no. 4, pp. 269-277, 2009.

[61] S. Phongpaicht, S. Preedana, N. Rungiondamai et al., "Biology activities of extracts from endophytic fungi isolated from Garcinia plants," Immunology and Medical Microbiology, vol. 51, pp. 517-525, 2007.

[62] L. Yu, Wheat Antioxidants, vol. 45, John Wiley \& Sons, New York, NY, USA, 2008.

[63] P. Molyneux, "Use of DPPH to estimate antioxidant activity," Journal of Science and Technology, vol. 26, p. 2, 2004.

[64] A. R. Ahmad, A. M. Mun'im, and B. Elya, "Study of antioxidant activity with reduction of DPPH radical and xanthine oxidase inhibitor of the extract of Ruella tuberosa L. leaf," International Research Journal of Pharmacy, vol. 3, no. 11, pp. 66-70, 2012. 

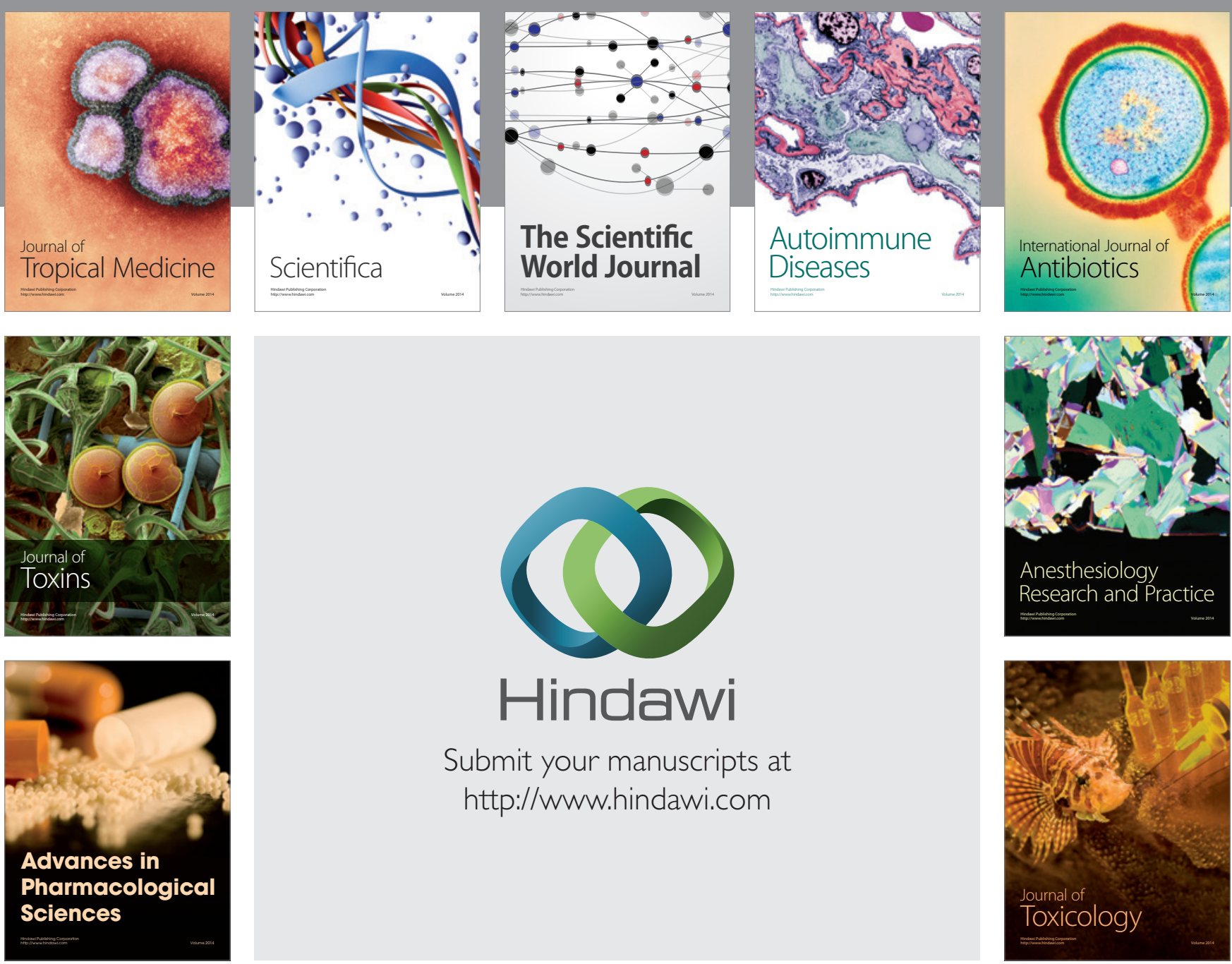

\section{Hindawi}

Submit your manuscripts at

http://www.hindawi.com
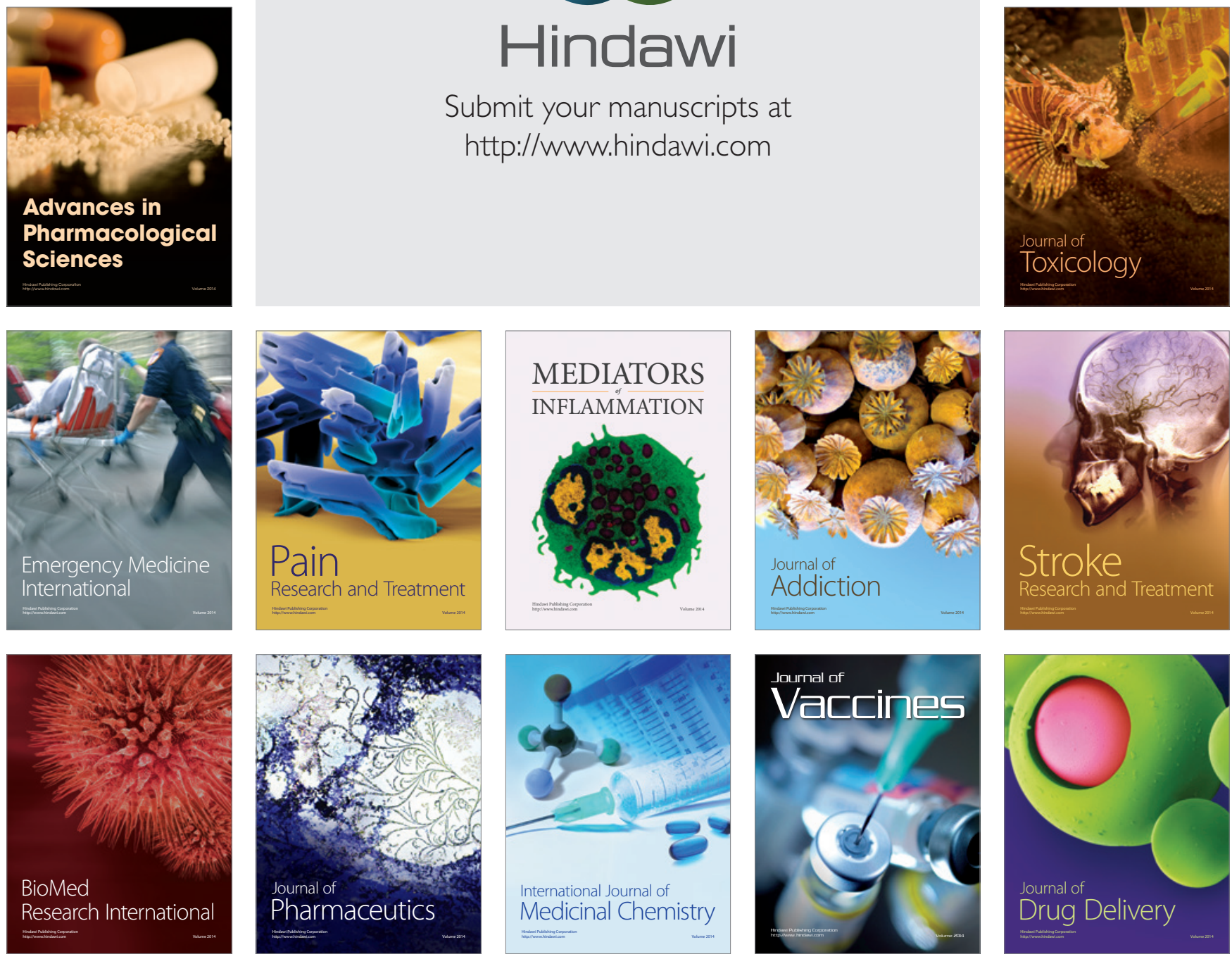